\author{
Bogusław BEMBENEK ${ }^{1}$ \\ Marzena FRANKOWSKA ${ }^{2}$ \\ Katarzyna KOWALSKA ${ }^{3}$
}

\title{
INTERNATIONALIZATION THROUGH NETWORKS - STRATEGIC CHALLENGE FOR CLUSTER FACILITATOR
}

\begin{abstract}
The article is focused on practical and cognitive approach to the facilitator activities in the area of cluster internationalization through networks. It presents considerations based on the Metalika Metal Cluster case study, results of the literature review and desk research. Secondary data in the research process was obtained from the websites of Polish Agency for Enterprise Development (PARP) and selected international networks. The article consists of four integral parts that concisely characterise the principal assumptions of the cluster internationalization through networks, the role and significance of the cluster facilitator activities within cluster development and its internationalization in the context of cluster management standards in Poland. Moreover, the article presents selected experiences and good practices of Metalika cluster facilitator related to implementation of the network model of internationalization. The studies clearly showed that nowadays a cluster facilitator is both an institution (cluster organisation, coordinator) and a person (cluster manager) working for the cluster development. The services offered by the facilitator to the cluster members are aimed at strengthening their development, including internationalization. This scope of facilitation is especially important for micro, small and medium enterprises (SMEs) that belong to the cluster. Due to the fact that cluster internationalization is usually a long and complex process of shaping cooperation within international space, it requires not only the full involvement, strategic thinking and actions of the facilitator and cluster members, but also the explicit support of external key stakeholders in turbulent environment.
\end{abstract}

Keywords: cluster, facilitator, service, internationalization, network, development.

\section{INTRODUCTION}

Taking into account the contemporary dynamic processes of economic globalisation, increased competition, and new requirements of the customers and stakeholders, it is often highlighted that shaping relations of Polish clusters at international level is not only a need, but a necessity. Cluster internationalization usually consists of the transition from its simple

\footnotetext{
${ }^{1}$ Bogusław Bembenek, PhD, Faculty of Management, Rzeszow University of Technology, Poland Rzeszow, corresponding author, e-mail: bogdanb@prz.edu.pl

${ }^{2}$ Marzena Frankowska, PhD, Faculty of Management and Economics of Services, University of Szczecin, Poland - Szczecin, e-mail: marzena.frankowska@wzieu.pl

${ }^{3}$ Katarzyna Kowalska, $\mathrm{PhD}$ student, World Economy Research Institute, Warsaw School of Economics, Poland - Warsaw, Vice-President of UNIMOS Foundation, e-mail: kkowalska@ unimos.global
} 
to increasingly complex forms and the dynamics of cluster development in this area depends on their internal and external conditions.

A universal motivation for internationalization of cluster members and facilitators (coordinators) is the idea that by acting together they are more effective in strengthening their potential and increasing their competitiveness. The level of cluster competitiveness is an essential criteria for a comprehensive assessment of clusters compared to other clusters at national and international level. Clusters with a high level of competitiveness often have the status of national key clusters, highlighting their strategic importance for the development of the economy.

Consciousness about the benefits of internationalization stimulates the cluster community to undertake various activities consistent with their development and internationalization strategy. Particularly under conditions of network economy the network model of internationalization it is very effective.

The aim of this article is to characterise the role and importance of facilitator services in the network approach to cluster internationalization. As part of such a defined goal, answers to three research questions were sought:

- what is the value of cluster internationalization through networks?

- why contemporary clusters need an facilitators?

- how facilitator systematic work is reflected in the network approach to cluster internationalization under conditions of globalisation?

The article presents only an outline of important issues and dominant views, directly related to the research problem which responds to the existing challenges created by the turbulent environment. The scientific deliberations were conducted based on selected research results obtained through literature review and desk research. The report from the nationwide cluster research elaborated by the Polish Agency for Enterprise Development (PARP) was a valuable source of secondary information.

The main reason for choosing the topic of the article and defining its scope is the fact that the internationalization of clusters is still a new area of research in Poland and therefore poorly set in the scientific literature. Although the research trend of the internationalization of individual enterprises is very popular today, it is relatively rare to carry out research studies in the field of cluster internationalization and its network approach. Thus, this article contributes to filling the existing knowledge gap and to stimulating creative and substantive discussion on the need for dynamic cluster management and shaping the competitiveness of clusters through their internationalization.

\section{CLUSTER INTERNATIONALIZATION THROUGH NETWORKS: THEORETICAL FRAMEWORK}

The cluster internationalization is often a long-term process of involvement in international operations, increasing international cooperation (e.g. cross-border activity) and integrating the cluster members into the very complex international environment. The scope or the degree of a cluster internationalization that is associated with the commitment to international markets may be measured by different variables, e.g. export level, the number of overseas markets, the number of foreign partners, and investment size.

A number of researchers and politicians suggest, that the cluster internationalization provides new opportunities for cluster members, especially for cluster SMEs. It can help 
these kind of firms to improve their competitiveness and accelerate their presence in global value chains ${ }^{4}$. Studies on clustering have also shown that the idea of business cluster there is an interconnection between economic-production and socio-cultural conditions, which significantly contribute to business profitability ${ }^{5}$.

In particular, the network approach to cluster internationalization (network model of cluster internationalization) makes cluster companies more robust and potentially more successful under conditions of globalisation. Networks, including industrial clusters, are complex adaptive or proactive systems which to a large extent is determined by endogenous and exogenous factors. Therefore, the internationalization behavior and performance of the cluster over time are not a simple sum of the activity of cluster members ${ }^{6}$.

The cluster structure makes the network approach to internationalization process of cluster have a dual character. The first relates to the development of strategic networks and is initiated by the cluster coordinator activity, and the second is the network connections of an operational nature between cluster members and their stakeholders. Scientific literature often emphasizes the positive influence of networks on internationalization ${ }^{7}$. The awareness of a networks power based on trust and credibility, and also skilled use of resources available through them make it possible to accelerate the process of internationalization and also increase the success from movement into a new foreign market. Networks have an important role in establishing the contacts, exchanging and forwarding knowledge about international activities in general and more exactly about particular cluster or region of a cluster rooting. Cluster internationalization through the networks relations can be viewed as a process, where a cluster attempts to establish relationship with different partners in foreign countries, develop its position in existing international networks, and effectively connect resources within different networks. This process requires correct understanding of cooperation goals, identifying the resources of cluster and specific network, and recognising the possibilities to use them and afterwards learn from the experiences of partners. Cluster facilitator and cluster members are keen to participate in networks, which offer them the ability to focus on achieving goals, solving specific problems and gain various perspectives on contemporary challenges created by turbulent environments.

Generally speaking, through networks it is possible for cluster members to access the tangible and intangible resources necessary for internationalization ${ }^{8}$. The international cooperation between cluster facilitators and cluster members can not only facilitate collaborative cross-border research, development and innovation projects, but also it can accelerate

${ }^{4}$ B. Bembenek, M. Frankowska, Cluster internationalization - a key component for the development and competitiveness of cluster members, "Modern Management Review" 2015, no. 22 (4), p. 31; Ch. Ampantzi, M. Psyllou, E. Diagkou, M. Glykas, Managing the SME clustering process life-cycle, [in:] Business process management, ed. M. Glykas, Springer, Berlin 2013, p. 418.

5 A. Chiara, Implementing sustainability strategies in networks and clusters, Springer, Cham 2017, p. 8.

${ }^{6}$ Y. Chandra, I.F. Wilkinson, Firm internationalization from a network-centric complex-system perspective, "Journal of World Business" 2017, no. 52, p. 692.

7 Y.K. Tang, The influence of networking on the internationalization of SMEs: evidence from internationalized Chinese firms, "International Small Business Journal" 2011, no. 29 (4), pp. 374-380; M. Zain, S.I. Ng, The impacts of networks relationships on SMEs' internationalization process, "Thunderbird International Business Review" 2006, no. 48 (2), p. 188.

${ }^{8} \mathrm{M}$. Seppo, The role of business networks in the internationalization of Estonian chemical industry enterprises, Tartu University Press, Tartu 2007, pp. 6-12. 
the development of world-class clusters. These type of clusters demonstrate the ability to develop strong cluster value chains owing to dynamic R\&D activity and international cooperation with key stakeholders. They are leading clusters that have a high level of performance and competitive capacities. Their ecosystem is an attractive spaces for the innovative firms, knowledge workers (best talents), and start-ups ${ }^{9}$. To achieve world-class excellence cluster should overcome contemporary challenges and their guiding principles which are the projection on to the world stage and moving up the value chain needs the ability to develop a global strategic vision, needs securing a position on the global market or generating new integrating markets on a global scale and also needs to know-how to control own value chain ${ }^{10}$.

Unfortunately, new cluster international collaboration for many cluster members is still determined by complication resulting from distance, language barriers and culture differences between the potential partners ${ }^{11}$. Furthermore, building too many international relationships of cluster through cluster facilitator is limited by coordination costs and the risk of relationship management in a diverse multinational environment. It is harder to respond quickly to partners signals. In turn, the performance of the cluster members within international networks can become increasingly dependent on the activities of international partners as key stakeholders ${ }^{12}$.

\section{CLUSTER FACILITATOR SERVICES FOR CLUSTER DEVELOPMENT}

According to M.B. Ingstrup and T. Damgaard even though some clusters develop purely organic and laissez-faire through the cluster life cycle, most clusters grow, however, with the support and active intervention from cluster facilitators ${ }^{13}$. In the theory and practice of clustering, the term cluster facilitator is often refers to an individual that manages the cluster and cluster initiatives ${ }^{14}$. The cluster facilitator is someone who engages in the activity of facilitation of cluster development in different ways. On the one hand, he or she acts as a cluster manager, and on the other hand as a formal or informal cluster organisation. In both cases, an entrepreneurial cluster facilitator can be considered a constitutive part of the cluster in all respects. It helps cluster members understand their common goals and achieve them. It also plays active role in cluster development, including its internationalization process. Its knowledge on the industrial sector is helpful in the implementation of many different functions and tasks, for example ${ }^{15}$ :

9 B. Bembenek, M. Frankowska, K. Havernikova, Cluster policy as a determining factor for development of world class-clusters, "Humanities and Social Sciences" 2016, no. 23 (4), p. 40.

${ }^{10}$ Ch. Ampantzi, M. Psyllou, E. Diagkou, M. Glykas, Managing the SME clustering..., p. 424.

11 B. Greenhalgh, Cluster internationalization, Manchester Metropolitan University, Manchester 2012, p. 42.

${ }^{12}$ M. Ratajczak-Mrozek, P. Mielcarek, Positive and negative effects of a company's relationships in the internationalization process, "Argumenta Oeconomica" 2017, no. 1 (38), p. 137.

${ }_{13}$ M.B. Ingstrup, T. Damgaard, Cluster facilitation from a cluster life cycle perspective, "European Planning Studies" 2013, no. 21 (4), p. 561.

${ }^{14} \mathrm{Ch}$. Ketels, G. Lindqvist, Ö. Sölvell, Cluster initiatives in developing and transition economies, Center for Strategy and Competitiveness, Stockholm 2006, p. 9.

15 D. Milojkovic, N. Stojkovic, Training for cluster facilitators in function of cluster development in Serbia, [in:] New challenges in changing labour markets, eds. J. Zubovic, I. Domazet, Institute of Economic Sciences, Belgrade 2012, p. 332. 
- identification of the possibilities and needs of industrial sector through analysis of capacities and demands of cluster members and establishing relevant internal and external networks,

- using and applying data and facts collected from cluster members as inputs for strategic management of cluster,

- building bridges to other clusters at regional, national or international levels through continuous promotion of partnerships among cluster members,

- continuous stimulation of internal networking (horizontal and vertical networking of cluster members), and externally to create opportunities for cross-border cooperation and networking with similar organisations, initiatives and partners that are important for operations of clusters and their members.

The cluster facilitator fundamental task is to help the cluster members increase their effectiveness by improving cluster strategy, process and structure. The facilitator helps cluster members create collaborative relationships, increase organisational learning and solve substantive common problems on cluster development by essentially lending them good suggestions and recommendations. Facilitation is difficult work, because it is mentally demanding, both cognitively and emotionally ${ }^{16}$.

Cluster facilitator as a cluster coordinator shall mean a legal entity which administers and develops internal and external relations that are really important for cluster activities, represents cluster interests and directly participates in the chain of activities intended for the development of the value chain of cluster ${ }^{17}$. Moreover, it based on own authority, knowledge and experience, as a cluster entrepreneur (clusterpreneur), takes on the role of broker - coupling firms with firms, firms with universities, and local government agencies with cluster members on a continuous basis ${ }^{18}$. M.B. Ingstrup and T. Damgaard argue that a cluster facilitator can play three key roles in cluster development ${ }^{19}$ :

- the framework - setting facilitator that focuses on the cluster ecosystem and has an indirect approach to facilitating through framework improving initiatives,

- the project facilitator who emphasises and engages in individual projects where a direct and interfering approach to facilitating actors, activities, and resources of clusters is prevailing, and then finally,

- the all-round facilitator which is the sum of the two previous roles.

Cluster facilitators are devoted to promoting local businesses through enhancing networking and sharing of activities and resources ${ }^{20}$. They play the various functions and roles in different type of clusters, for example in Marshallian/Italian industrial district type of

${ }^{16}$ R. Schwarz, The skilled facilitator approach, [in:] The skilled facilitator: a comprehensive resource for consultants, facilitators, managers, trainers, and coaches, John Wiley \& Sons Inc, Hoboken 2002, p. 29.

${ }^{17}$ E. Dervinyte, Concept of the development of the Lithuanian clusters, Ministry of Economy of the Republic of Lithuania, Vilnius 2014, p. 2.

${ }^{18}$ T. Andersson, S. Serger, J. Sörvik, E.W. Hansson, The cluster policies whitebook, International Organisation for Knowledge Economy and Enterprise Development, Malmö 2004, p. 100.

${ }_{19}$ M.B. Ingstrup, T. Damgaard, Cluster facilitation..., p. 563.

${ }^{20}$ M.B. Ingstrup, T. Damgaard, Cluster development through public sector facilitation, [in:] Resources and competitive advantage in clusters, (eds.) K. Brown, J. Burgess, M. Festing, S. Royer, Rainer Hampp Verlag, München 2013, p. 47. 
clusters - play the role of match makers and organisers, in the hub-and-spoke district type of clusters - perform the roles of developers and organisers, in the satellite industrial platform type of clusters - promoters and organisers, and in the state-anchored industrial district type of clusters - fulfill the roles of integrators and organisers ${ }^{21}$.

An effective cluster facilitator is professional, flexible, adaptive, proactive, responsive, resilient, honest, responsible, and really involved in cluster development. Professional cluster manager as a cluster facilitator with own emotional intelligence, strategic thinking, systemically acting, leadership and communication skills, good motivation and committed advocating for interests of cluster members can contribute to progressive and sustainable cluster development ${ }^{22}$. Efficient cluster facilitation is usually based on entrepreneurial, leadership, mediation and arbitration skills ${ }^{23}$. In addition to strong technical and analytical skills, facilitators also possess an ability to build trust among cluster members, and to direct the project without leading $\mathrm{it}^{24}$.

\section{FACILITATOR SERVICES FOR CLUSTER INTERNATIONALIZATION THROUGH NETWORKS: BASED ON RESEARCH OF POLISH AGENCY FOR ENTERPRISE DEVELOPMENT}

The network approach to cluster internationalization in Poland is included directly in 3 out of 36 standards of cluster management that have been defined in 2014 within initiative of the Polish Agency for Enterprise Development (PARP). This standards are supposed to directly stimulate efficiency in the cluster management process and thus, they are characterised by a high universality of application regardless of the sector of the economy represented by the cluster. According to the 3 basic standards concerning the network approach to internationalization, the main tasks of the cluster facilitator $\operatorname{are}^{25}$ :

- supporting networking and matchmaking at national and international level by organising different business missions, study visits and business to business (B2B) meetings aimed at establishing cooperation between cluster members and their potential partners;

- supporting the cluster internationalization by identifying potential foreign partners, conducting negotiations, establishing cooperation agreements, organising meetings with foreign partners, undertaking marketing activities and joining international network organisations;

- participation in the meetings with national and international cluster representatives (e.g. clusters facilitators) aimed at establishing and cooperation and jointly execute common projects (inter-clustering cooperation).

\footnotetext{
${ }^{21}$ M.B. Ingstrup, Facilitating different types of clusters, "Management Revue" 2013, no. 24 (2), p. 133.

22 D. Milojkovic, N. Stojkovic, Training for cluster facilitators ..., p. 336.

${ }^{23}$ I. Oleniuch, The role of network facilitators in the development of clusters, "Research Papers of Wrocław University of Economics" 2015, no. 402, p. 254; L. Palmen, M. Baron, Przewodnik dla animatorów inicjatyw klastrowych, PARP, Warszawa 2016, p. 148.

${ }^{24}$ Inter-American Development Bank, Cluster best practices for the Caribbean private sector development, Inter-American Development Bank, Washington 2010, p. 8.

${ }^{25}$ D. Frączek, P. Kryjom, Standardy zarzadzania klastrem, PARP, Warszawa 2016, pp. 25-28.
} 
At the same time it was assumed that the scope of the cluster facilitator activities in this area should be adequate to the level of development and the needs of the cluster members. The presented standards are obligatory for the majority of clusters, besides embryonic clusters.

In 2015, the PARP carried out the first nationwide verification of the quality level of cluster management in relation to the defined cluster management standards ${ }^{26}$. The research was carried out on the basis of an in-depth personal interview and self-evaluation tool of 64 cluster facilitators. It should be noted that 5 clusters were in the embryonic phase, 58 in the growth/development phase, and only 1 in the maturity phase (Table 1).

Polish clusters represent different stages of cluster life cycle. Therefore, an analysis of the PARP project outcomes, especially with regard to the unfulfilled standards, allows for drafting a conclusion that public support for clusters should be continued, especially for cluster organisations in order to help them solve the key problems in managing their clusters. It is worth to undertake joint efforts (e.g. by cooperation of cluster coordinator with local government) aimed at overcoming weaknesses in cluster management, since well performing and efficiently managed clusters as a group of potential Key National Clusters can bring more benefits to the economy. Such clusters are characterised by their significance to economy and international competitiveness. To obtain the status, a cluster has to fulfil certain criteria related to critical mass, development potential, innovation capacity, quality of cooperation, cluster coordinator experience and achievements ${ }^{27}$.

Table 1. Assessment of the cluster facilitators activities in terms of compliance with cluster management standards $(\mathrm{N}=64)$

\begin{tabular}{|l|c|c|c|}
\hline $\begin{array}{l}\text { cluster management standards - } \\
\text { in the area network approach to } \\
\text { internationalization }\end{array}$ & $\begin{array}{c}\text { embryonic clusters } \\
\mathbf{n = 5}\end{array}$ & $\begin{array}{c}\text { growth clusters } \\
\mathbf{n = 5 8}\end{array}$ & $\begin{array}{c}\text { mature cluster } \\
\mathbf{n = 1}\end{array}$ \\
\hline $\begin{array}{l}\text { S1: activity of matchmaking and } \\
\text { networking }\end{array}$ & $3^{*}\left(2^{* *}\right)$ & $56^{*}\left(2^{* *}\right)$ & $1^{*}$ \\
\hline $\begin{array}{l}\text { S2: supporting the cluster interna- } \\
\text { tionalization }\end{array}$ & $4^{*}\left(1^{* *}\right)$ & $56^{*}\left(2^{* *}\right)$ & OB \\
\hline $\begin{array}{l}\text { S3: supporting the inter-clustering } \\
\text { cooperation }\end{array}$ & $4^{*}\left(1^{* *}\right)$ & $56^{*}\left(2^{* *}\right)$ & OB \\
\hline
\end{tabular}

${ }^{*}$ standard is met, ** standard is not met, OB - obligatory standard

Source: Own elaboration based on: D. Frączek, P. Kryjom, Weryfikacja standardów zarządzania..., pp. 38, 51-54.

The research results showed that the activity of the cluster facilitator in the mature phase was consistent with all standards related to network approach to internationalization (Table 1). A similar situation applied to the majority of the facilitators representing growing clusters. In the case of embryonic clusters, it was found that for their facilitators the activity of matchmaking and networking was slightly more problematic than supporting the cluster internationalization and inter-clustering cooperation. In the context of the other 33 cluster management standards it was identified that during the research period the level of clusters

${ }^{26}$ D. Frączek, P. Kryjom, Weryfikacja standardów zarządzania w wybranych klastrach - edycja 2015, PARP, Warszawa 2016, pp. 6-54.

${ }^{27}$ Ibidem, p. 7; http://www.pi.gov.pl/eng/chapter_95931.asp (access: 1.12.2017). 
development in Poland varied considerably. Differences in the assessment of clusters resources and facilitators services were particularly noticeable. In turn, the studied clusters differed to a much lesser extent in terms of their cooperation with the environment and internal organisation.

\section{TOWARDS IMPLEMENTATION OF NETWORK APPROACH TO INTERNATIONALIZATION: A CASE STUDY OF METALIKA CLUSTER}

The structure of the Metalika Metal Cluster was established in March 2011 as the bottom-up initiative. It is located in the north-western part of Poland. The strategic aim of cluster is the dynamic development of cluster members by expanding the range of internal and external cooperation (domestic and foreign). The structure of the cluster, which is unique on a national scale in terms of the resources and abilities of the its members, enables the comprehensive implementation of orders placed by the metal industry and represent interregional cooperation. The cluster resources are characterised by high technological innovation which affects the usefulness of the products and services being offered. Cluster brings together companies from the metal industry and connected sectors operating in the Zachodniopomorskie (West Pomeranian), Wielkopolskie (Greater Poland), and Pomorskie (Pomeranian) Voivodeships. The cluster companies operate in the following branches: maritime, off-shore, construction, agricultural, automotive (trucks and buses), vehicle diagnostics, wind farms and environmental preservation, cycling, advanced machines and equipment for metal processing. The cluster currently has 45 members. Its key stakeholders can be divided into four groups: members and partners, including the companies operating within metal industry value chain (suppliers, manufacturers, wholesalers and distributors, service operators, etc.), R\&D institutions, regional authority and the supporting organisations $^{28}$.

The cluster facilitator (institutional coordinator) is the company MP Polish Cluster Ltd. Its aim is to support cluster members in long-term cooperation based on networking, knowledge transfer, implementation of innovative solutions and the improvement of competitiveness of the companies forming the cluster. Since 2016, the cluster has been a content partner for the smart specialisation of the West-Pomeranian Region "Advanced metal products". Almost all of the cluster companies have experience in cooperating with foreign partners, especially those from German and Scandinavian markets. The export of the companies is up to approximately $50 \%$. Internationalization is a strategic direction of the cluster development and from the beginning of its existence many activities have been undertaken in this area. Therefore, cluster coordinator initiated cluster research entitled "Cooperation in the cluster" which was carried out in January 2015. The selected results of the study showed that ${ }^{29}$ :

- cluster firms were selling products and services to more than three foreign markets,

- the main export market of the cluster companies was Europe, especially Germany, although there were some notable commercial activities outside Europe,

\footnotetext{
${ }^{28} \mathrm{http}: / /$ polskieklastry.org/metalika-metal-cluster/ (access: 1.02.2018).

${ }^{29}$ M. Frankowska, U. Grosse, S. Zenk, Regions, clusters and SMEs: the challenges of cross-border cooperation as in the example of Brandenburg and West-Pomerania [in:] Clusters as a driving power of the European economy, eds. H. Drewello, M. Helfer, M. Bouzar, Nomos, Baden-Baden 2016, pp. 251-272.
} 
- companies wanted to focus mainly on the European market (primarily Norway, as well as Germany and Switzerland, or Denmark and Finland),

- $40 \%$ of the respondents were in favour of increasing the level of cooperation with German partners as suppliers,

- cluster firms were most in favour of the intensification of cooperation with German companies as clients, and to cooperate within R\&D projects, then as suppliers.

The network approach to internationalization of the Metalika cluster is a strategic area of the cluster development. It requires strong cooperation with external key cluster stakeholders. Cluster facilitator being aware of the value of internationalization through networks, has been taking active actions in this area for several years (Table 2).

Table 2. Initial stage of the network approach to internationalization of the Metalika cluster

\begin{tabular}{|c|c|}
\hline Area of activities & Examples activities of cluster facilitator and cluster members \\
\hline $\begin{array}{l}\text { international conferences, } \\
\text { seminars and brokerage- } \\
\text { events }\end{array}$ & $\begin{array}{l}\text { Clusters as Drivers of Competitiveness: Strategies and Policy Issues } \\
\text { - Fribourg 2011; European Cluster Collaboration - Vienna 2012; } \\
\text { Metal Industry Cluster Brandenburg Conference - Eisenhuttenstadt } \\
\text { 2013, Ludwigsfelde } 2014 \text { and Hennigsdorf 2017; Regions, industry } \\
\text { and advanced manufacturing - Brussels 2014; European Cluster Days } \\
\text { - Strasbourg 2015; 2nd Cluster-to-cluster conference and matchmak- } \\
\text { ing - towards new horizons - Berlin 2014; 3rd Cluster-to-Cluster Con- } \\
\text { ference and Matchmaking - Copenhagen 2015; Cluster World Con- } \\
\text { gress - Dąbrowa Górnicza 2015; Cluster policy and cooperation of } \\
\text { clusters within the V4 + } 4 \text { countries - Warszawa } 2017\end{array}$ \\
\hline $\begin{array}{l}\text { international - trade and } \\
\text { economic missions, study } \\
\text { visits, trade fairs and expo- } \\
\text { sitions }\end{array}$ & $\begin{array}{l}\text { EMO Hannover } 2012 \text { - workshops with Metal Industry Cluster Bran- } \\
\text { denburg, signing the Memorandum of Understanding; Hannover } \\
\text { Messe } 2017 \text { - meeting with Metal Industry Cluster Brandenburg, ex- } \\
\text { change of clusters experiences, presentation of the Metalika cluster at } \\
\text { regional exposition in national pavilion }\end{array}$ \\
\hline international projects & $\begin{array}{l}\text { project "Applying energy efficient measures for metal and metal- } \\
\text { working SMEs and industry" (2016-2019) is focus on provide enter- } \\
\text { prises with innovative technical, commercial and financial tools in } \\
\text { order to overcome the existing barriers that hinder the adoption of } \\
\text { energy saving measures; the project with budget } 1717456,25 \text { EUR is } \\
\text { implemented in an international partnership of } 7 \text { entities - from Spain } \\
\text { (2), Italy (2), France (1) and Poland (2); five out of the seven project } \\
\text { partners are enterprises/trade associations (with } 7000 \text { associated com- } \\
\text { panies) that will ensure that a critical mass is achieved; numerous pro- } \\
\text { ject meetings e.g. Pamplona } 2016 \text {, Brescia } 2016 \text {, Lyon } 2017 \text { foster } \\
\text { the development of cooperation between project members }\end{array}$ \\
\hline $\begin{array}{l}\text { activities supporting the } \\
\text { cluster internationalization } \\
\text { within cluster ecosystem }\end{array}$ & $\begin{array}{l}\text { receiving foreign guests at cluster meetings - } 2012 \text { to } 2017 \text {; distribu- } \\
\text { tion of inquiries or seeking investors, contractors for cluster compa- } \\
\text { nies; help to applying for funds for internationalization of cluster } \\
\text { SMEs }\end{array}$ \\
\hline
\end{tabular}

Source: own elaboration. 
The Metalika cluster cooperation with the Brandenburg-Berlin Metal Cluster started practically from the conference organised in Szczecin 2012 as part of the PARP initiative named "Polish clusters and cluster policy". During the conference, the representative of the Metal Cluster Brandenburg-Berlin presented the cluster mission, strategy, goals and offered of cooperation with Polish partners, as well as the advantages of the Brandenburg region. Conversations during the conference initiated the cooperation of both clusters. The first working meeting of partners took place in Szczecin. The next step initial stage of international cooperation were the meetings at the largest metal and machine industry trade fair EMO 2013 in Hanover and the signing of a Memorandum of Understanding, which has strategic, intercultural and supra-regional dimension. The event was organised within joint workshop entitled "Building bridges - setting up the cluster cooperation between the Metal Cluster Metalika and the Metal Cluster Brandenburg". Their goal was to determine the areas of cooperation between the two clusters in the near future. The subject of the workshop was divided into two parts: cooperation in the field of R\&D projects and personnel training for the needs of the metal and machinery industry ${ }^{30}$.

With the involvement of cluster members there were identified specific fields of possible technology cooperations such as Industry 4.0 (e.g. in the frame of the Horizon 2020) or to collaboration with regard to educational and qualification requirements for the metal industry in both Brandenburg and West-Pomerania. Cluster members participated in the annual Cluster Conference Metal Brandenburg, entitled in 2013 as „Synergie with steel”, along with a B2B brokerage meeting. The following event to which cluster members had been invited in 2014 was the seminar "Horizon 2020 - Elevator Pitch" in Hannover. During annual cluster conference in Brandenburg a discussion was undertaken regarding common research on the needs of enterprises in terms of cross-border cooperation ${ }^{31}$.

Currently, the facilitator of the Metalika cluster is analysing different possibilities to join several international networks (Table 3).

Contemporary challenges, related to the globalisation of the world economy, force the cluster to become more involved in network cooperation. Various benefits of belonging to international networks can create new opportunities. In particular, the network perspective on cluster internationalization is very important for cluster SMEs.

The facilitator of Metalika cluster is aware of the benefits that result from joining international networks whose profile is compatible with the activities of cluster members. It belief that the success of any cluster depends on its ability to forge strategic relations with international partners. Nevertheless, facilitator activity for cluster internationalization is strongly limited, mainly by the low availability of public financing for cluster development in Poland. Public authorities have provided support in this area mainly for clusters with the status of Key National Clusters. At regional level, there are support programme for clusters within Regional Operational Programs, but the public assistance offered to them is usually limited to clusters from a given voivodship. For this reason, clusters representing own members from different neighbouring provinces, such as the Metalika cluster, can not benefit from this kind of financing.

\footnotetext{
30 http://www.pi.gov.pl/PARP/chapter_86197 (access: 1.02.2018).

${ }^{31}$ M. Frankowska, U. Grosse, S. Zenk, Regions, clusters and SMEs..., pp. 251-272.
} 
Table 3. Potential cooperation of Metalika cluster within selected international networks

\begin{tabular}{|c|c|}
\hline Network & Scope of activity \\
\hline $\begin{array}{l}\text { European Association of } \\
\text { Mining Industries, Metal } \\
\text { Ores \& Industrial Miner- } \\
\text { als (Euromines) }\end{array}$ & $\begin{array}{l}\text { Network is the recognised representative of the European metals and } \\
\text { minerals mining industry and represents } 19 \text { national European federa- } \\
\text { tions and } 28 \text { companies as direct members from the whole of Europe. } \\
\text { It serves as a network for cooperation and for the exchange of infor- } \\
\text { mation throughout the sector within Europe. }\end{array}$ \\
\hline $\begin{array}{l}\text { Metallurgy } \\
\text { Europe - Eureka }\end{array}$ & $\begin{array}{l}\text { Network facilitator has headquarters in Ulm (Germany). Members of } \\
\text { the network are various entities connected directly or indirectly with } \\
\text { metallurgy through business activities and in the area of R+D, including } \\
\text { from countries such as: Austria, Belgium, Canada, Cyprus, Czech Re- } \\
\text { public, Denmark, Estonia, Finland, France, Germany, Hungary, Ire- } \\
\text { land, Italy, Luxembourg, Malta, Norway, Portugal, Spain, Sweden, } \\
\text { Switzerland, The Netherlands, The UK, Turkey, and Poland. Network } \\
\text { is focussed on identifying and tackling the research areas with the high- } \\
\text { est potential for innovation and industrial application. Moreover, it in- } \\
\text { spire cross-collaboration across many sectors of industry spanning e.g. } \\
\text { transport, green energy, renewable, aerospace, biomedical, computing, } \\
\text { chemistry, and manufacturing. }\end{array}$ \\
\hline $\begin{array}{l}\text { PROMETIA } \\
\text { Association }\end{array}$ & $\begin{array}{l}\text { Network is an international non-profit association promoting innova- } \\
\text { tion in mineral processing and extractive metallurgy for mining and re- } \\
\text { cycling of raw materials. It aims to strengthen European technical skills } \\
\text { and industrial know-how in raw materials processing and support in- } \\
\text { dustrial and economic development. }\end{array}$ \\
\hline $\begin{array}{l}\text { TCI - The global practi- } \\
\text { tioners network for com- } \\
\text { petitiveness, clusters and } \\
\text { innovation }\end{array}$ & $\begin{array}{l}\text { TCI was founded in 1998. It is a network of people (business leaders, } \\
\text { cluster managers, policy makers, researchers, consultants) and organi- } \\
\text { sations (cluster organisations, networks, universities, firms, na- } \\
\text { tional\&regional development agencies, etc.), with the common objec- } \\
\text { tive of making their regions and clusters more competitive (members } \\
\text { located around the world). It is the leading global network of main or- } \\
\text { ganisations and practitioners with deep expertise in clusters and com- } \\
\text { petitiveness, who collaborate in a unique open, flexible and practical } \\
\text { context to advance in the practice of competitiveness, innovation and } \\
\text { cluster development. }\end{array}$ \\
\hline
\end{tabular}

Source: http://www.euromines.org; http://metallurgy-europe.eu; http://prometia.eu; http://www.tcinetwork.org.

\section{CONCLUSIONS}

Theoretical and empirical studies show that, the connections with foreign partners may concern both various areas of cluster activity and individual links of its members in the its value chain. Proactive and reactive motives for cluster internationalization determine strategic choices in the cluster, including those regarding the way and form of cluster internationalization. In order to meet the requirements of global competition, cluster members with their facilitator increasingly decide to cooperate internationally in various types of networks. In addition, it should be emphasized that, vibrant clusters are often the initiators of international networking. 
Cluster internationalization through networks has a qualitative and quantitative character, which favours the development and growth of the cluster. On the one hand, it is shaped by the international activity of individual cluster members, and on the other, by the entrepreneurial activity of the cluster facilitator (cluster coordinator). It creates a number of benefits, e.g. it is a source of increased competitive strength and expansion, supporting the development of relational capital, enabling the conversion of tacit to explicit knowledge, facilitating access to global production factors and new markets, and stimulating the emergence and development of new forms cooperation between business and R\&D.

However, cluster internationalization through networks requires a large amount of work by the cluster facilitator, e.g. fostering trust within cluster and networks, knowledge management, preparation of cluster internationalization strategy, acquisition of foreign partners for cooperation, selection of international events (conferences, congresses, fairs etc.) favouring networking, determination of mechanisms and conditions for the participation of members in this kind of events, and preparation of promotional materials. Also, counteracting language barriers in the internationalization process often requires a cluster facilitator to provide a specialised translation (in the context of the cluster industry) for cluster SMEs, for example during joint foreign trips and organisation of study visits.

The background of facilitator activities within cluster internationalization through networks outlined in this article can be a source of inspiration for further deeper research and scientific discussions that contribute to the development of knowledge in this area. The presented research results, generalisations and suggestions can be helpful in creating positive changes in the improvement of the cluster management process.

\section{REFERENCES}

1. Ampantzi Ch., Psyllou M., Diagkou E., Glykas M., Managing the SME clustering process life-cycle [in:] Business process management, ed. M. Glykas, Springer, Berlin 2013.

2. Andersson T., Serger S., Sörvik J., Hansson E.W., The cluster policies whitebook, International Organisation for Knowledge Economy and Enterprise Development, Malmö 2004.

3. Bembenek B., Frankowska M., Cluster internationalization - a key component for the development and competitiveness of cluster members, "Modern Management Review" 2015, no. 22 (4), pp. 31-46.

4. Bembenek B., Frankowska M., Havernikova K., Cluster policy as a determining factor for development of world class-clusters, "Humanities and Social Sciences" 2016, no. 23 (4), pp. 33-56.

5. Chandra Y., Wilkinson I.F., Firm internationalization from a network-centric complex-system perspective, "Journal of World Business" 2017, no. 52, pp. 691-701.

6. Chiara A., Implementing sustainability strategies in networks and clusters, Springer, Cham 2017.

7. Dervinyte E., Concept of the development of the Lithuanian clusters, Ministry of Economy of the Republic of Lithuania, Vilnius 2014.

8. Frankowska M., Grosse U., Zenk S., Regions, clusters and SME's: the challenges of crossborder cooperation as in the example of Brandenburg and West-Pomerania, [in:] Clusters as a driving power of the European economy, eds. H. Drewello, M. Helfer, M. Bouzar, Nomos, Baden-Baden 2016.

9. Frączek D., Kryjom P., Standardy zarzadzania klastrem, PARP, Warszawa 2016. 
10. Frączek D., Kryjom P., Weryfikacja standardów zarządzania w wybranych klastrach - edycja 2015, PARP, Warszawa 2016.

11. Greenhalgh B., Cluster internationalization, Manchester Metropolitan University, Manchester 2012.

12. Ingstrup M.B., Damgaard T., Cluster development through public sector facilitation, [in:] Resources and competitive advantage in clusters, (eds.) K. Brown, J. Burgess, M. Festing, S. Royer, Rainer Hampp Verlag, München 2013.

13. Ingstrup M.B., Damgaard T., Cluster facilitation from a cluster life cycle perspective, "European Planning Studies" 2013, no. 21 (4), pp. 556-574.

14. Ingstrup M.B., Facilitating different types of clusters, "Management Revue" 2013, no. 24 (2), pp. 133-150.

15. Inter-American Development Bank, Cluster best practices for the Caribbean private sector development, Inter-American Development Bank, Washington 2010.

16. Ketels Ch., Lindqvist G., Sölvell Ö., Cluster initiatives in developing and transition economies, Center for Strategy and Competitiveness, Stockholm 2006.

17. Milojkovic D., Stojkovic N., Training for cluster facilitators in function of cluster development in Serbia, [in:] New challenges in changing labour markets, eds. J. Zubovic, I. Domazet, Institute of Economic Sciences, Belgrade 2012.

18. Oleniuch I., The role of network facilitators in the development of clusters, "Research Papers of Wrocław University of Economics" 2015, no. 402, pp. 251-260.

19. Palmen L., Baron M., Przewodnik dla animatorów inicjatyw klastrowych, PARP, Warszawa 2016.

20. Ratajczak-Mrozek M., Mielcarek P, Positive and negative effects of a company's relationships in the internationalization process, "Argumenta Oeconomica" 2017, no. 1 (38), pp. 121-144.

21. Schwarz R., The skilled facilitator approach [in:] The skilled facilitator: a comprehensive resource for consultants, facilitators, managers, trainers, and coaches, John Wiley \& Sons Inc, Hoboken 2002.

22. Seppo M., The role of business networks in the internationalization of Estonian chemical industry enterprises, Tartu University Press, Tartu 2007.

23. Tang Y.K., The influence of networking on the internationalization of SMEs: evidence from internationalized Chinese firms, "International Small Business Journal" 2011, no. 29 (4), pp. 374-398.

24. Zain M., Ng S.I., The impacts of networks relationships on SMEs' internationalization process, "Thunderbird International Business Review" 2006, no. 48 (2), pp. 183-205.

\section{INTERNET SOURCES}

1. http://metallurgy-europe.eu/list-of-all-members/ (access: 1.02.2018).

2. http://polskieklastry.org/metalika-metal-cluster/ (access: 1.02.2018).

3. http://prometia.eu/objectives/ (access: 1.02.2018).

4. http://www.euromines.org/who-we-are/become-member (access: 1.02.2018).

5. http://www.pi.gov.pl/eng/chapter_95931.asp (access: 1.12.2017).

6. http://www.pi.gov.pl/PARP/chapter_86197 (access: 1.02.2018).

7. http://www.tci-network.org/about_us (access: 1.02.2018). 


\section{INTERNACJONALIZACJA POPRZEZ SIECI - STRATEGICZNE WYZWANIE DLA FACYLITATORA KLASTRA}

Artykuł koncentruje się na poznawczym i praktycznym podejściu do aktywności facylitatora w zakresie internacjonalizacji klastra poprzez sieci. Przedstawia rozważania, które są oparte na studium przypadku Klastra Metalowego Metalika, analizie literatury przedmiotu i danych zastanych (metoda desk research). Informacje wtórne pozyskano ze stron internetowych Polskiej Agencji Rozwoju Przedsiębiorczości (PARP) oraz wybranych międzynarodowych sieci. Artykuł składa się z czterech integralnych części, w których w sposób syntetyczny scharakteryzowano istotę i główne założenia koncepcji internacjonalizacji klastra poprzez sieci, rolę i znaczenie facylitatora w procesie rozwoju klastra i jego internacjonalizacji w kontekście standardów zarządzania klastrem w Polsce. Ponadto zaprezentowano wybrane doświadczenia i dobre praktyki facylitatora klastra Metalika związane z implementacją modelu sieciowego internacjonalizacji. Przeprowadzone badania wykazały jednoznacznie, że współcześnie facyilitatorem klastra może być zarówno instytucja (organizacja klastrowa, koordynator), jak i osoba (menedżer klastra), działająca na rzecz rozwoju klastra. Oferowane przez facylitatora różnorodne usługi członkom klastra sprzyjają ich rozwojowi, w tym wzmocnieniu poziomu ich internacjonalizacji. Jest to szczególnie istotne dla mikro, małych i średnich firm klastra. Z uwagi na fakt, że internacjonalizacja klastra to często długotrwały i złożony proces kształtowania współpracy w przestrzeni międzynarodowej, tym samym wymaga nie tylko pełnego zaangażowania, strategicznego myślenia i działania facylitatora i członków klastra, ale także wymiernego wsparcia zewnętrznych kluczowych interesariuszy w turbulentnym otoczeniu.

Słowa kluczowe: klaster, facylitator, usługa, internacjonalizacja, sieć, rozwój.

DOI: $10.7862 /$ rz.2018.hss.1

Przestano do redakcji: grudzień 2017 r.

Przyjęto do druku: kwiecień 2018 r. 